\title{
ANALISIS PENGARUH PERCEIVED SERVICE QUALITY TERHADAP PEMANFAATAN INSTALASI RAWAT JALAN
}

\author{
Puryanti \\ Program Studi Administrasi Rumah Sakit, STIKES Yayasan RS. Dr. Soetomo, Surabaya, Indonesia \\ email: puryanti@stikes-yrsds.ac.id
}

\begin{abstract}
Abstrak
Salah satu indikator mutu pelayanan rawat jalan di rumah sakit adalah peningkatan jumlah kunjungan pasien rawat jalan. Mutu pelayanan menjadi faktor penentu bagi pasein untuk memanfaatkan pelayanan. Kunjungan pasien rawat jalan di Rumah Sakit Bhayangkara H.S. Samsoeri Mertojoso selama empat tahun terakhir belum semuanya mengalami peningkatan sesuai target capaian rumah sakit. Tujuan penelitian ini adalah menganalisis pengaruh perceived service quality terhadap pemanfaatan rawat jalan di Rumah Sakit Bhayangkara H.S. Samsoeri Mertojoso. Jenis penelitian ini adalah penelitian diskriptif analitik dengan rancang bangun penelitian cross sectional. Sampel penelitian ini adalah pasien rawat jalan sebesar 90 sampel dengan teknik accidental sampling. Analisis data menggunakan uji regresi ordinal. Hasil penelitian menunjukkan bahwa technical quality petugas baik (mean $\geq 3,50$ ). Functional quality yang terdiri dari Attitude dan behavior petugas sudah baik (mean $\geq 3,50$ ), accessibility dan flexibility sudah baik (mean $\geq 3,50$ ), reliability dan trustworthiness sudah baik (mean $\geq 3,50$ ), service recovery kurang baik (mean $<3,50$ ), dan service scape kurang baik (mean 33,50). Pemanfaatan pelayanan rawat jalan masih sedang. Hasil uji regresi ordinal menunjukkan bahwa technical quality tidak berpengaruh terhadap pemanfaatan rawat jalan. Functional quality berpengaruh terhadap pemanfaatan rawat jalan. Kesimpulan penelitian ini adalah secara keseluruhan perceived service quality berpengaruh terhadap pemanfaatan rawat jalan.
\end{abstract}

Kata kunci: perceived service quality, pemanfaatan

\begin{abstract}
One indicator of the quality of outpatient services at the hospital is an increase in the number of outpatient visits. Service quality is a determining factor for patiens to take advantage of services. Outpatient visit at Bhayangkara H.S. Samsoeri Martojoso Hospital during the last four years has not all improved according to the hospital's achievement. The purpose of this study was to analyze the effect of perceived service qualiy on outpatient utilization at Bhayangkara H.S. Samsoeri Martojoso Hospital. This research was descriptive analytics research with cross-sectional design. The sample of this study was outpatients for 90 samples with accidental sampling technique. Data analysis uses ordinal linear regression test. The results showed that the technical quality of the officers is good (mean $\geq 3,50$ ). Functional quality consisting of attitude and behavior of officers is good (mean $\geq 3,50$ ), accessibility and flexibility are good (mean $\geq 3,50)$, reliability and trustworthiness are good (mean $\geq 3,50$ ), service recovery is not good (mean<3,50), and service scape is not good (mean <3,50). The level of utilization of outpatient services is still moderate. The results of the ordinal regression test showed thad technical quality had not effect on outpatient utilization. Functional quality affects outpatient utilization. The conclusion of this study is that overall perceived service quality has an effects on outpatient utilization.
\end{abstract}

Keywords: perceived service quality, utility

\section{PENDAHULUAN}

Saat ini pembangunan dibidang kesehatan sudah memasuki era globalisasi dengan segala dampak positif dan negatifnya. Salah satu dampak nyata yang ditimbulkan adalah adanya kompetisi dan perkembangan yang cukup tinggi dalam rangka merebut pasar. Rumah sakit menurut
Undang Undang Republik Indonesia Nomor 44 tahun 2009 adalah institusi pelayanan kesehatan yang menyelenggarakan pelayanan kesehatan perorangan secara paripurna yang menyediakan pelayanan rawat inap, rawat jalan dan gawat darurat. Era globalisasi tidak hanya menjadi peluang tetapi juga merupakan ancaman bagi 
perkembangan rumah sakit dimana persaingan rumah sakit semakin tinggi. Untuk tetap bertahan dan berkembang rumah sakit harus berupaya meningkatkan kualitas pelayanan sesuai dengan ketentuan atau standar pelayanan rumah sakit karena kualitas memberikan peranan penting bagi pelayanan jasa termasuk rumah sakit (Alma, 2016).

Saat ini tingkat pemahaman masyarakat semakin tinggi dalam menilai kualitas pelayanan di rumah sakit. Tingginya pemahaman ini menyebabkan masyarakat semakin kritis dan menuntut kualitas pelayanan yang bagus (Gunawan \& Djati, 2011). Penilaian masyarakat terhadap kualitas pelayanan produk atau jasa dapat ditentukan dengan expected quality dan perceived quality. Jadi pengukuran tingkat kualitas pelayanan rumah sakit ditentukan oleh penilaian dan persepsi konsumen terhadap pelayanan yang diberikan (Tjiptono, 2011). Rumah sakit yang tidak mampu menjaga dan meningkatkan kualitas pelayanan akan mengalami penurunan jumlah kunjungan (Cristina, 2014).

Gronroos memperkenalkan pendekatan untuk menilai kualitas pelayanan dengan menggunakan perceived service quality. Penilian kualitas pelayanan ini didasarkan pada persepsi pelanggan terhadap layanan pada saat evaluasi pasca pembelian (Hayati \& Mahmudah, 2016). Pelanggan bisa melakukan penilaian kualitas pelayanan setelah menggunakan atau menerima pelayanan rumah sakit. Perceived service quality yang baik merupakan jaminan untuk menciptakan dan mempertahankan kesetiaan pasien terhadap pemanfaatan pelayanan rumah sakit. Perceived quality pelayanan rumah sakit dapat menjadi pertimbangan bagi pasien untuk memanfaatkan pelayanan rumah sakit kembali.

Rumah sakit harus dapat memahami perceived service quality yang dirasakan oleh pasien. Persepsi ini sebagai bentuk yang melandasi kepercayaan pasien terhadap pelayanan yang diberikan rumah sakit. Tingkat kepercayaan konsumen terhadap produk atau jasa akan digunakan sebagai bahan pertimbangan konsumen dalam memanfaatkan kembali pelayanan (Kotler \& Keller, 2011).

Penelitian terdahulu tentang kualitas bahwa kualitas pelayanan memiliki pengaruh terhadap minat pasien dalam memanfaatkan pelayanan di rumah sakit. Jadi untuk meningkatkan pemanfaatan pelayanan, rumah sakit harus meningkatkan kualitas pelayanan yang diberikan ke pasien (Amalia Davina, 2018). Perceived service quality ditinjau dari semua dimensinya memiliki pengaruh yang signifikan terhadap pemanfaatan ulang pelayanan rumah sakit. Hasil penelitian ini menunjukkan bahwa sebagain besar pasien yang memanfaatkakan kembali pelayanan rumah sakit memiliki persepsi yang baik terhadap semua dimensi kualitas layanan (Herwanda et al., 2018).

Rumah Sakit Bayangkara H.S. Samsoeri Mertojoso adalah rumah sakit kelas B milik POLRI yang melayani masyarakat umum. Kunjungan pelayanan rawat jalan di Rumah Sakit Bhayangkara H.S. Samsoeri Mertojoso selama empat tahun terakhir yaitu tahun 2017 sampai 2020 belum semuanya mencapai target capaian yang ditentukan oleh rumah sakit. Adanya persentase kunjungan yang belum mencapai target memberikan indikasi bagi rumah sakit untuk melakukan analisis pasien berdasarkan kebutuhan, keinginan, dan utilisasi. Dari analisis kebutuhan, keinginan, dan utilisasi ini rumah sakit akan mengetahui persepsi kualitas pelayanan pada pemanfaatan pelayanan rawat jalan. Berbagai upaya telah dilakukan oleh rumah sakit untuk meningkatkan jumlah kunjungan rawat jalan agar mencapai target yaitu dengan meningkatkan kualitas pelayanan dan sarana prasarana secara terus menerus. Diharapkan dengan peningkatan kualitas dan sarana prasarana ini dapat meningkatkan pemanfaatan kunjungan rawat jalan. Hal ini sesuai dengan tujuan yang ingin dicapai oleh sebuah rumah sakit yaitu meningkatkan market share dan memaksimalkan kunjungan rawat jalan dan rawat inap rumah sakit (Kotler \& Keller, 2011).

Berdasarkan hal di atas, peneliti tertarik untuk melakukan penelitian tentang pengaruh perceived service quality terhadap pemanfaatan Rawat Jalan di Rumah Sakit Bayangkara H.S. Samsoeri Mertojoso. Penelitian ini bertujuan untuk mengidentifikasi karakteristik pasien, mengidentifikasi pemanfaatan, mengidentifikasi perceived service quality yang terdiri technical quality dan functional quality. Serta menganalisis pengaruh perceived service quality terhadap pemanfaatan rawat jalan di Rumah Sakit Bayangkara H.S. Samsoeri Mertojoso.

\section{METODE PENELITIAN}

Penelitian ini adalah penelitian deskriptif analitik. Rancang bangun penelitian adalah cross sectional. Penelitian ini dilakukan di Rumah Sakit Bhayangkara H.S. Samsoeri Mertojoso pada Bulan Desember 2019 sampai Bulan Februari 2020. Populasi penelitian adalah pasien rawat jalan di Rumah Sakit Bhayangkara H.S. Samsoeri Mertojoso dengan besar sampel penelitian 90 responden. Teknik pengambilan sampel menggunakan Teknik accidental sampling. Teknik 
pengumpulan data penelitian menggunakan alat bantu lembar kuesioner.

Variabel penelitian ini meliputi karakteristik responden, pemanfaatan, perceived service quality. Variabel perceived service quality yang diteliti terdiri dari technical quality dan functional quality. Technical quality meliputi profesionalism dan skills. Functional quality meliputi attitude dan behavior, acesibility dan flexibility, reliability dan trustworthiness, service recovery, dan service scape.

Teknik analisis data menggunakan uji regresi ordinal untuk mengetahui pengaruh perceived service quality terhadap pemanfaatan rawat jalan. Perceived service quality yang meliputi technical quality dan functional quality sebagai variabel bebas dan pemanfaatan rawat jalan sebagai variabel terikat. Penilaian menggunakan kriteria apabila nilai mean $\geq$ 3,50 berarti baik dan nilai mean $<3,50$ berarti kurang baik (Supriyanto \& Djohan, 2011).

\section{HASIL DAN PEMBAHASAN}

\section{a. Karakteristik Responden}

Karakteristik responden yang diteliti di Rumah Sakit Bhayangkara H.S. Samsoeri Mertojoso terdiri dari jenis kelamin, umur, pendidikan, pekerjaan, pendapatan keluarga, dan kepesertaan asuransi yang dapat dilihat pada tabel 1.

Tabel 1. Karakteristik Responden Berdasarkan Jenis Kelamin, Umur, Pendidikan, Pekerjaan, Pendapatan Keluarga, dan Kepesertaan Asuransi di Rumah Sakit Bhayangkara H.S. Samsoeri Mertojoso

\begin{tabular}{|c|c|c|}
\hline Karakteristik & $\mathbf{n}$ & $\%$ \\
\hline \multicolumn{3}{|l|}{ Jenis Kelamin } \\
\hline Laki-laki & 20 & 22.2 \\
\hline Perempuan & 70 & 77.8 \\
\hline \multicolumn{3}{|l|}{ Umur } \\
\hline 18-30 tahun & 11 & 12.2 \\
\hline 30-45 tahun & 51 & 56.7 \\
\hline$>45-60$ tahun & 19 & 21.1 \\
\hline$>60$ tahun & 10 & 11,1 \\
\hline \multicolumn{3}{|l|}{ Pendidikan } \\
\hline SD & 1 & 1.1 \\
\hline SMP & 8 & 8.9 \\
\hline SMA & 49 & 54,4 \\
\hline PT & 32 & 35.6 \\
\hline \multicolumn{3}{|l|}{ Pekerjaan } \\
\hline Tidak bekerja & 37 & 41.1 \\
\hline Wiraswasta & 36 & 40,0 \\
\hline PNS & 8 & 8,9 \\
\hline POLRI/TNI & 9 & 10,0 \\
\hline \multicolumn{3}{|l|}{ Pendapatan Keluarga } \\
\hline$\leq$ UMR Kota Surabaya Rp 3.800 .000 & 35 & 38.9 \\
\hline > UMR Kota Surabaya Rp 3.800.000-Rp 5.000.000 & 38 & 42.2 \\
\hline$>\operatorname{Rp} 5.000 .000$ & 17 & 18.9 \\
\hline \multicolumn{3}{|l|}{ Kepesertaan Asuransi } \\
\hline BPJS & 74 & 82.2 \\
\hline Umum & 11 & 12.2 \\
\hline Asuransi lain & 5 & 5.6 \\
\hline
\end{tabular}

Berdasarkan tabel 1 diketahui bahwa mayoritas responden berjenis kelamin perempuan yaitu sebesar $77,8 \%$. Sebagian besar responden berada pada kelompok umur 30-45 tahun yaitu sebesar $56,7 \%$ dan yang terkecil berada pada kelompok umur $>60$ tahun sebesar $11,1 \%$. Pendidikan sebagian besar responden adalah lulus Sekolah Menengah Atas (SMA) yaitu sebesar
54,4\% dan Perguruan Tinggi sebesar 35,6\%. Sedangkan responden yang lulus Sekolah Menengah Pertama sebesar 8,9\% dan lulus SD sebesar $1,1 \%$. Jadi rata-rata responden memiliki kategori tingkat pendidikan menengah dan tinggi.

Mayoritas pekerjaan responden adalah tidak bekerja yaitu sebesar $41,1 \%$. Responden yang tidak bekerja ini adalah sebagai ibu rumah tangga. 
Sedangkan Sebagian kecil pekerjaan responden adalah PNS yaitu sebesar $8,9 \%$. Pendapatan keluarga responden yang terbanyak berada pada kisaran Rp. 3.800.000 - Rp. 5.000.000,- yaitu sebesar $42,2 \%$ dan hanya $18,9 \%$ yang memiliki pendapatan >Rp. 5.000.000,-. Sebagian besar responden yang memanfaatkan pelayanan rawat jalan di Rumah Sakit H.S. Samsoeri Mertojoson merupakan pasien BPJS yaitu sebesar $82,2 \%$.
$12,2 \%$ adalah pasien umum yaitu pasien yang tidak menggunakan asuransi. Sedangkan responden yang menggunakan asuransi selain BPJS sebesar 5,6\%.

\section{b. Pemanfaatan Intsalasi rawat Jalan}

Pemanfataan instalasi rawat jalan di RS. Bhayangkara H.S. Samsoeri Mertojoso Surabaya dapat dilihat pada tabel 2 yaitu:

Tabel 2. Pemanfaatan Rawat Jalan RS. Bhayangkara H.S. Samsoeri Mertojoso Surabaya

\begin{tabular}{clccc}
\hline No. & Pemanfaatan & n & Persentase $(\boldsymbol{\%})$ \\
\hline 1 & Rendah (1-2 kunjungan) & 25 & 27.8 \\
2 & Sedang (4-5 kunjungan) & 46 & 51,1 \\
3 & Tinggi (>5 kunjungan) & 19 & 21.1 \\
\hline \multicolumn{2}{r}{ Total } & $\mathbf{9 0}$ & $\mathbf{1 0 0 , 0}$ \\
\hline
\end{tabular}

Pemanfaatan adalah frekuensi kunjungan responden di rawat jalan RS. Bhayangkara H.S. Samsoeri Mertojoso Surabaya selama 3 (tiga) tahun terakhir. Berdasarkan tabel 2 diketahui bahwa pemanfaatan rawat jalan Rumah Sakit Bhayangkara H.S Samsoeri Mertojoso berada pada tingkatan sedang yaitu sebesar $51,1 \%$.
Sedangkan $21,1 \%$ pemanfaatan berada pada tingkatan tinggi.

\section{c. Perceived Service Quality}

Perceived service quality merupakan penilaian kualitas pelayanan yang didasarkan pada persepsi pelanggan terhadap layanan rumah sakit yang dapat dilihat pada tabel 3 .

Tabel 3. Perceived Service Quality Rawat Jalan RS. Bhayangkara H.S. Samsoeri Mertojoso

\begin{tabular}{lcc}
\hline \multicolumn{1}{c}{ Perceived Service Quality } & Mean & Keterangan \\
\hline $\begin{array}{l}\text { Technical quality } \\
\text { Profesionalism and skills dokter } \\
\text { Profesionalism and skills perawat }\end{array}$ & 3,50 & Kurang Baik \\
Functional quality & 3,50 & Kurang Baik \\
Attitudes dan behavior dokter & & \\
Attitudes dan behavior perawat & 3,61 & Baik \\
Accesibility dan flexibility & 3,53 & Baik \\
Reliability dan trustworthiness & 3,53 & Baik \\
Service recovery & 3,50 & Baik \\
Service scape & 3,46 & Baik \\
\hline
\end{tabular}

Dimensi perceived service quality yang dinilai meliputi technical quality dan functional quality. Technical quality meliputi persepsi kualitas pelayanan terkait profesionalism and skills dokter dan perawat yang dinilai sudah baik oleh responden yaitu dengan nilai mean 3,50 untuk profesionalism and skills doker dan nilai mean 3,50 untuk profesionalism and skills perawat. Sedangkan untuk functional quality ada 6 aspek yang dinilai. Persepsi responden terhadap aspek attitudes dan behavior dokter, attitudes dan behavior perawat, accesibility dan flexibility, dan reliability dan trustworthiness sudah baik dengan nilai mean $\geq 3,50$. Hanya aspek service recovery dan service scape yang dinilai responden masih kurang baik dengan nilai mean $<3,50$.

\section{d. Pengaruh Perceived Service Quality terhadap Pemanfaatan Instalasi Rawat Jalan}

Analisis pengaruh perceived service quality terhadap pemanfaatan rawat jalan dapat dilihat pada tabel 4. 
Tabel 4. Pengaruh Perseived Service Quality Terhadap Pemanfaatan Rawat Jalan di RS.Bhayangkara H.S. Samsoeri Mertojoso Surabaya

\begin{tabular}{lcc}
\hline \multicolumn{1}{c}{ Variabel } & Sig & Keterangan \\
\hline Technical quality & 0,150 & Tidak signifikan \\
Functional quality & 0,012 & Signifikan \\
Perseived service quality & 0,015 & Signifikan \\
\hline
\end{tabular}

Analisis pengaruh perceived service quality yang meliputi dimensi technical quality (profesionalism and skills) dan fungtional quality (attitudes dan behavior, accesibility dan flexibility, reliability dan trustworthiness, service recovery dan service scape) terhadap pemanfaatan rawat jalan di RS. Bhayangkara H.S. Samsoeri Mertojoso Surabaya dalam penelitian ini menggunakan analisis regresi ordinal. Berdasarkan hasil uji regresi ordinal diketahui bahwa technical quality tidak ada pengaruh terhadap pemanfaatan rawat jalan dengan nilai signifikansi 0,150 . Sedangkan functional quality ada pengaruh terhadap pemanfaatan rawat jalan dengan nilai signifikansi 0,012. Secara keseluruhan perceived service quality berpengaruh terhadap pemanfaatan rawat jalan dengan nilai signifikansi 0,015 .

Beberapa variabel karakteristik individu yang diidentifikasi dalam penelitian ini meliputi jenis kelamin, umur, pendidikan, pekerjaan, pendapatan, dan kepesertaan asuransi. Jenis kelamin merupakan salah satu faktor pembeda dalam pemanfaatan pelayanan kesehatan. Perempuan mempunyai kecenderungan untuk lebih banyak menggunakan fasilitas pelayanan kesehatan dibandingkan dengan laki-laki (Kotler \& Keller, 2011). Setiap individu memiliki kecenderungan untuk menggunakan pelayanan kesehatan yang berbeda-beda. Berdasarkan hasil penelitian diketahui bahwa $77,8 \%$ pasien rawat jalan RS. Bhayangkara H.S. Samsoeri Mertojoso Surabaya adalah perempuan. Pasien usia tua cenderung lebih cepat puas dibandingkan dengan pasien yang lebih muda. Pasien usia muda akan lebih kritis dalam menilai kualitas pelayanan rumah sakit. Hasil penelitian menunjukkan pasien di RS. Bhayangkara H.S. Samsoeri Mertojoso Surabaya masih tergolong muda atau kelompok dewasa (3045 tahun). Kelompok umur dewasa merupakan rentang usia produktif. Hal ini sesuai dengan pendapat Kotler \& Keller (2011) bahwa usia mempunyai pengaruh yang penting terhadap penilaian produk dan perilaku dalam pemanfaatan produk. Tingkat pendidikan menjadi pertimbangan konsumen untuk mencari pengetahuan pelayanan Kesehatan. Hasil penelitian menunjukkan bahwa mayoritas pasien rawat jalan di RS. Bhayangkara H.S. Samsoeri Mertojoso berpendidikan SMA dan perguruan tinggi. Pendidikan dapat mempengaruhi perilaku pasien untuk mencari pelayanan kesehatan. Masyarakat dengan pendidikan tinggi akan menuntut produk yang berkualitas (Kotler \& Keller, 2011).

Pendapatan merupakan faktor ekonomi yang dapat mempengaruhi konsumen dalam menentukan pemanfaatan pelayanan kesehatan. Hasil penelitian menunjukkan bahwa pasien yang memanfaatkan pelayanan rawat jalan RS. Bhayangkara H.S. Samsoeri Mertojoso Surabaya adalah keluarga menengah ke bawah yaitu $42,2 \%$ pendapatan keluarganya Rp. > UMR Kota Surabaya - Rp. 5.000.000,- dan 38.9\% pendapatan keluarganya $\leq$ UMR Surabaya Rp. 3.800.000,. Pasien memilih memanfaatkan pelayanan rawat jalan di RS. Bhayangkara H.S. Samsoeri Mertojoso Surabaya karena melayani peserta BPJS. Hal ini sesuai dengan hasil penelitian bahwa $82,2 \%$ pasien yang berobat di rawat jalan RS. Bhayangkara H.S. Samsoeri Mertojoso Surabaya adalah pasien BPJS.

Pemanfaatan pelayanan kesehatan merupakan hasil interaksi antara konsumen sebagai pengguna layanan kesehatan dengan provider sebagai penyedia pelayanan kesehatan. Dalam penelitian ini pemanfaatan berdasarkan pada tingkat frekuensi kunjungan responden di Rawat Jalan selama 3 (tiga) tahun terakhir. Pemanfaatan dibagi menjadi 3 (tiga) kategori yaitu tinggi bila frekuensi kunjungan $>5$ kali, sedang bila frekuensi kunjungan $4-5 \mathrm{kali}$, dan rendah bila frekuensi kunjungan $1-3$ kali. Ada berbagai faktor penentu seseorang dalam menentukan pemanfaatan diantaranya yaitu kependudukan, sosial, sumber keluarga, sumber daya, organisasi dan sistem kesehatan (Tjiptono, 2011). Pemanfaatan pelayanan rawat jalan di RS. Bhayangkara H.S. Samsoeri Mertojoso masih pada tingkat sedang yaitu sebesar $51,1 \%$. Sebagian besar responden memilih memanfaatkan pelayanan di RS. Bhayangkara H.S. Samsoeri Mertojoso karena rumah sakit melayani BPJS serta tarif pelyanan yang masih wajar dan terjangkau bila dibandingkan dengan rumah sakit lain. Persepsi 
tentang biaya pelayanan kesehatan bisa menjadi pertimbangan untuk pemanfaatan pelayanan oleh pasien (Atmoko \& Budiadi, 2017).

Variabel perceived service quality meliputi dimensi technical quality dan functional quality. Tecknical quality terdiri dari profesionalism and skills (Hayati \& Mahmudah, 2016). Penilaian terhadap profesionalism and skills meliputi profesionalism and skills dokter, dan perawat. profesionalism and skills yang dinilai terkait ketrampilan, ketelitian, pengalaman, kejelasan komunikasi dokter, perawat dalam memberikan pelayanan. Hal ini menjadi yang mendasar dalam pelayanan kesehatan jasa karena merupakan inti dari produk pelayanan yang diberikan di rumah sakit. Berdasarkan hasil penelitian profesionalism and skills dokter dan perawat dalam hal ketrampilan, ketelitian, pengalaman dan kejelasan komunikasi dokter sudah baik dengan nilai mean $\geq 3,50$. Dokter selalu memberikan penjelasan mengenai penyakit. Perawat selalu memberikan informasi terkait pelayanan dan jadwal kedatangan dokter. Perawat juga selalu berada di ruang poli sebelum jadwal poli buka sehingga pasien bisa dengan mudah untuk mendapatkan informasi kepastian jam kedatangan dokter. Adanya kejelasan komunikasi perawat dengan pasien terkait pelayanan dokter ini memberikan ketenangan bagi pasien sehingga pasien tidak komplain meskipun ada keterlambatan kedatangan dokter.

Berdasarkan hasil uji regresi ordinal antara technical quality yang meliputi profesionalism and skills tenaga dokter dan perawat terhadap pemanfaatan rawat jalan di RS. Bhayangkara H.S. Samsoeri Mertojoso Surabaya diketahui bahwa profesionalism and skills dokter dan profesionalism and skills perawat tidak memiliki pengaruh signifikan terhadap pemanfaatan rawat jalan di RS. Bhayangkara H.S. Samsoeri Mertojoso Surabaya. Dalam penelitian terdahulu disebutkan bahwa kualitas interaksi petugas dalam memberikan pelayanan memiliki pengaruh terhadap kepuasan yang akan mempengaruhi pasien dalam memanfaatkan pelayanan kesehatan di masa datangg (Nugraha et al., 2018). Penelitian lain yang dilakukan Armadeni et al., (2018) bahwa perceived service quality dalam benak pasien memiliki pengaruh besar terhadap keputusan pasien untuk memanfaatkan layanan kesehatan. Penilaian konsumen mengenai kualitas pelayanan terkait orang atau pemberi pelayanan, peralatan, dan komunikasi dapat mempengaruhi keputusan untuk melakukan pemanfaatan kembali di masa mendatang (Jihan \& Made, 2018).
Pasien puas akan berfikir untuk memanfaatkan kembali pelayanan. Hal ini dapat dilihat dari frekuensi pemanfaatan pasien terhadap pelayanan rawat jalan di RS. Bhayangkara H.S. Samsoeri Mertojoso Surabaya dimana frekuensi pemanfaatan pasien berada pada tingkat sedang. Jadi meskipun technical quality tidak berpengaruh terhadap pemanfaatan pelayanan, RS. Bhayangkara H.S. Samsoeri Mertojoso Surabaya harus tetap meningkatkan kualitas pelayanan dalam hal ini profesionalism and skills tenaga dokter dan profesionalism and skills tenaga perawat.

Dimensi fungtional quality berkaitan erat dengan proses layanan yang diterima pelanggan. Functional quality menurut Gronroos dalam (Hayati \& Mahmudah, 2016) meliputi attitudes dan behavior, accesibility dan flexibility, reliability dan trustworthiness, service recovery dan service scape. Penilaian terhadap attitudes dan behavior meliputi kesopanan, keramahan dan kesediaan mendengarkan dan merespon keluhan pasien yang diberikan dokter dan perawat dalam memberikan pelayanan di rawat jalan RS. Bhayangkara H.S. Samsoeri Mertojoso Surabaya.

Attitudes dan behavior dokter dan perawat secara keseluruhan dinilai sudah baik. Pasien menilai petugas rawat jalan di RS. Bhayangkara H.S. Samsoeri Mertojoso Surabaya sangat sopan dan ramah dalam memberikan pelayanan pada pasien. persepsi responden terhadap attitudes dan behavior dokter dan perawat dapat menjadi pertimbangan bagi pasien untuk memanfaatkan pelayanan di rumah sakit (Roza et al., 2019).

Penilaian accesibility dan flexibility, pelanggan meliputi kemudahan mengakses lokasi pelayanan, prosedur pelayanan dan jadwal/jam pelayanan di rawat jalan RS. Bhayangkara H.S. Samsoeri Mertojoso Surabaya. Secara keseluruhan accesibility dan flexibility dinilai sudah baik. Responden menilai prosedur penerimaan pasien dilayani cepat dan tidak berbelit-belit, dokter datang tepat waktu, dokter/perawat selalu siap melayani pasien, dan lokasi pelayanan mudah diakses pasien.

Penilaian reliability dan trustworthines meliputi ketepatan diagnosis dokter dan terapi dokter cepat memberikan kesembuhan bagi pasien Rawat Jalan RS. Bhayangkara H.S. Samsoeri Mertojoso Surabaya. Secara keseluruhan reliability dan trustworthines dinilai sudah baik. Pasien menilai diagnosa yang diberikan sudah tepat sesuai dengan keluhan pasien. Terapi obat yang dierikan dokter juga sudah bagus. Pasien menganggap dokter yang ada di rawat jalan RS. Bhayangkara 
H.S. Samsoeri Mertojoso Surabaya memiliki kemampuan yang bagus.

Penilaian service recovery meliputi ketanggapan dokter dan perawat dalam mengatasi masalah atau hambatan yang dialami pasien selama proses pelayanan di rawat jalan RS. Bhayangkara H.S. Samsoeri Mertojoso Surabaya dinilai kurang baik. Pasien merasa saat ada masalah atau hambatan terkait pelayanan pasien, respon petugas perawat cukup lama dalam mengatasinya sehingga pasien harus menunggu untuk mendapatkan solusi atau arahan dari petugas. Responden berharap hasil ini bisa menjadi masukan bagi Rumah Sakit H.S Samsoeri Mertojoso untuk melakukan perbaikan.

Penilaian service scape meliputi fasilitas rumah sakit, kebersihan, kerapian, lahan parkir, kenyamanan ruang pemeriksaan dan ruang tunggu, kamar mandi, dan fasilitas pemasaran rumah sakit. Responden menilai service scape dinilai masih kurang baik bila dibandingkan dengan rumah sakit lain. Fasilitas pelayanan yang disediakan rumah sakit dapat mempengaruhi kepuasan pasien yang akan menjadi pertimbangan bagi pasien untuk melakukan pemanfaatan ulang (Harfika \& Abdullah, 2017). Oleh karena itu responden berharap supaya Rumah Sakit Bhayangkara H.S. Samsoeri Mertojoso dapat memperbaiki fasilitas yang ada.

Berdasarkan hasil uji regresi ordinal diketahui bahwa variabel functional quality yang meliputi attitudes dan behavior, accesibility dan flexibility, reliability dan trustworthiness, service recovery dan service scape memiliki pengaruh signifikan terhadap pemanfaatan rawat jalan di RS. Bhayangkara H.S. Samsoeri Mertojoso Surabaya. Dari hasil uji ini, bila RS. Bhayangkara H.S. Samsoeri Mertojoso Surabaya ingin meningkatkan pemanfaatan pelayanan maka rumah sakit harus memperbaiki variabel yang ada pada semua dimensi dalam functional quality yang meliputi attitudes dan behavior, accesibility dan flexibility, reliability dan trustworthiness, service recovery dan service scape. Artinya bahwa semakin baik functional quality yang diberikan oleh rumah sakit maka semakin tinggi pula pemanfaatan pasien terhadap rawat jalan di RS. Bhayangkara H.S. Samsoeri Mertojoso Surabaya (Hamid, 2015). Perceived service quality digunakan sebagai pedoman untuk membantu perusahaan memahami arti kualitas layanan dibenak pelanggan yang meliputi kualitas teknis (tecknical quality) dan kualitas functional (functional quality). Selain itu perceived service quality dapat menjadi dasar untuk memanfaatkan pelayanan. Bila perceived service quality baik maka pemanfaatan akan tinggi (Irma Asriani et al., 2019).

Berdasarkan hasil uji regresi ordinal diketahui bahwa perceived service quality secara keseluruhan memiliki pengaruh yang signifikan terhadap pemanfaatan pelayanan rawat jalan di RS. Bhayangkara H.S. Samsoeri Mertojoso Surabaya. Hal ini dapat digunakan sebagai pertimbangan bagi rumah sakit apabila rumah sakit ingin meningkatkan jumlah pemanfaatan pelayanan maka rumah sakit harus memperbaiki perceivd service quality yang ada di rawat jalan RS. Bhayangkara H.S. Samsoeri Mertojoso Surabaya. Hal ini sesuai dengan penelitian yang dilakukan oleh Hamid (2015) yang menyatakan bahwa perceivd service quality akan mempengaruhi kepuasan konsumen. Menurut (Roza et al., 2019) konsumen yang puas dengan pelayanan yang diberikan akan mendorong konsumen tersebut untuk menggunakan kembali pelayanan yang ada yang secara otomatis akan meningkatkan pemanfaatan pelayanan di rumah sakit. Peningkatan kualitas pelayanan ini akan mempengaruhi konsumen dalam berperilaku dalam pemanfaatan pelayanan dimasa dating (Armadani et al., 2018).

\section{KESIMPULAN DAN SARAN}

Penelitian ini menyimpulkan bahwa pemanfaatan rawat jalan di Rumah Sakit H.S. Samsoeri Mertojoso masih pada tingkat sedang. Technical quality yang terdiri dari profesionalism and skills dokter dan profesionalism and skills perawat sudah baik. Functional quality yang terdiri dari attitudes dan behavior, accesibility dan flexibility, dan reliability dan trustworthiness sudah baik. Hanya service recovery dan service scape yang masih dinilai kurang baik. Berdasarkan hasil uji regresi ordinal didapatkan bahwa technical quality tidak berpengaruh terhadap pemanfaatan rawat jalan. Functional quality berpengaruh terhadap pemanfaatan rawat jalan. Sedangkan secara keseluruhan perceived service quality berpengaruh terhadap pemanfaatan rawat jalan.

Perceived service quality dan pemanfaatan pelayanan yang baik dapat meningkatkan brand image sehingga terbentuk loyalitas pasien sebagai tujuan jangka panjang rumah sakit. Oleh karena itu perlu dilakukan penelitian lanjutan mengenai analisis pengaruh Perceived Service Quality dan brand image terhadap tingkat loyalitas pasien di Rumah Sakit Bhayangkara H.S. Samsoeri Mertojoso. 


\section{REFERENSI}

Alma, B. (2016). Manajemen Pemasaran dan Pemasaran Jasa (dua belas). Alfabeta.

Amalia Davina, et al. (2018). Hubungan Indeks Kepuasan Pasien tentang Mutu Pelayanan Dimensi Kehandalan dengan Minat Berobat Kembali di RSD Kalisat Kabupaten Jember ( Correlation between Patient Satisfaction Index in Reliability of Service Quality and Utility at RSD Kalisat Jember ). 6(2), 278-284.

Armadani, F. N., Supriyadi, S., \& Ulfah, N. H. (2018). Hubungan Brand Equity (Brand Awarenees, Brand Associations, Perceived Quality) dengan Keputusan Pemanfaatan Klinik Laktasi di Rumah Sakit Muhammadiyah Lamongan. Preventia: The Indonesian Journal of Public Health, 3(1), 49. https://doi.org/10.17977/um044v3i1p49-65

Atmoko, W. B., \& Budiadi, N. A. (2017). Kekuatan Harga Dalam Membentuk Niat Berobat Ulang Di Rumah Sakit. Jurnal Manajemen, 12(1), 118.

Cristina, F. S. (2014). Pengaruh Kualitas Pelayanan dan Citra Korporasi terhadap Kesetiaan Pelanggan melalui Kepuasan Pelanggan. Jurnal Mnajemen Dan Pemasaran Jasa, 7, 91-124.

Gunawan, K., \& Djati, S. P. (2011). Kualitas Layanan dan Loyalitas Pasien (Studi pada Rumah Sakit Umum Swasta di Kota Singaraja-Bali). Jurnal Manajemen Dan Kewirausahaan, 13(1). https://doi.org/10.9744/jmk.13.1.32-39

Harfika, J., \& Abdullah, N. (2017). Pengaruh Kualitas Pelayanan Dan Fasilitas Terhadap Kepuasan Pasien Pada Rumah Sakit Umum Kabupaten Aceh Barat Daya. Balance, XIV(1), 44-56. File:///E:/Semester 6/Sinta Kepercayaan, Fasilitas/Fasilitas (9).Pdf

Hayati, N., \& Mahmudah, A. S. (2016). Analysis of Gronroos Service Quality Dimensions for Pospay Service and Mail Delivery on Customer Satisfaction ( Study in Indonesia ). 7(4), 717725.
Herwanda, Putra, E. D., \& Putri, L. Y. (2018). Pengaruh Perceived Quality Pasien Terhadap Pemanfaatan Ulang Pelayanan Kesehatan Gigi Dan Mulut Di Rsgm Unsyiah. Cakradonya Dental Journal, 9(1), 16-25. https://doi.org/10.24815/cdj.v9i1.9873

Irma Asriani, Usman, \& Makhrajani Majid. (2019). Pengaruh Ekuitas Merek Terhadap Keputusan Pemanfaatan Pelayanan Rawat Jalan Rumah Sakit Ibu Dan Anak Ananda Trifa Kota Parepare. Jurnal Ilmiah Manusia Dan Kesehatan, 2(3), 354-366. https://doi.org/10.31850/makes.v2i3.178

Jihan, N., \& Made, S. I. (2018). Analisis pengaruh kualitas layanan, harapan kinerja dan citra perusahaan terhadap loyalitas pelanggan melalui kepuasan pelanggan sebagai variabel intervening (Studi pada Rumah Sakit Islam Sultan Agung Semarang). Diponegoro Journal of Management, $\quad 7(1984), \quad 8$. https://ejournal3.undip.ac.id/index.php/djo $\mathrm{m} /$ article/view/22339

Kotler, P., \& Keller, K. (2011). Manajemen Pemasaran (13th ed.). Erlangga.

Nugraha, K. S. W., Suryaningsih, I. B., \& Paramita, C. (2018). Pengaruh ElemenElemen Healthcare Service Quality (Hcsq) Terhadap Kepuasan Pasien Rumah Sakit Bina Sehat Jember. Bisma, 12(3), 323. https://doi.org/10.19184/bisma.v12i3.9002

Roza, Y. D., Sumarwan, U., \& Yuliati, L. N. (2019). Persepsi pasien tentang kualitas pelayanan dan minat kunjungan ulang di unit rawat jalan rs unand tahun 2019. Jurnal Kesehatan Masyarakat Andalah, 13(2), 27-33.

Supriyanto, \& Djohan. (2011). Metodologi Riset Bisnis dan Kesehatan. PT. Grafika Wangi Kalimantan.

Tjiptono, F. (2011). Pemasaran Jasa. Bayumedia Publishing. 